\title{
MATRIX ROCK TEXTURE IN THE PITINGA TOPAZ GRANITE, AMAZONAS, BRAZIL
}

\section{SARA LAIS RAHAL LENHARO ${ }^{1}$, PETER JOHN POLLARD ${ }^{2}$ AND HELMUT BORN $^{3}$}

\begin{abstract}
The porphyritic topaz granite of the Água Boa batholith at the Pitinga Mine contains rounded quartz and rectangular white and pink feldspar phenocrysts. The fine-grained groundmass is composed of quartz, white and pink feldspar, micas (biotite and Li-siderophylite) and topaz. Accessory minerals include zircon, fluorite, Fe-Ti oxides, RE-minerals, thorite, columbite-tantalite, cassiterite, xenotime and sulphides. The topaz granite is peraluminous, similar to low $\mathrm{P}_{2} \mathrm{O}_{5}$ topaz granites, shows some features resulting from post-magmatic metassomatic processes and is considered as a likely source of tin mineralizing fluids in the Agua Boa Granite. Three subtypes of topaz granite have been identified, based on modal composition and petrographic features: 1) end-member with around 20\% angular phenocrysts; 2 ) intermediate member with approximately $36 \%$ phenocrysts exhibiting dendritic margins; and 3) matrix rock containing around $68 \%$ phenocrysts and phenocryst aggregates with irregular and dendritic margins. The estimated amount of K-feldspar phenocrysts decreases at the expense of quartz and plagioclase phenocrysts from the matrix rock to the end-member type. Petrographically, the matrix rock contains relict quartz, Kfeldspar and plagioclase aggregates of the older, medium- to coarse-grained granite facies. These aggregates are surrounded by irregular and anastomosing films of topaz granite displaying magmatic flow textures. Individual phenocrysts of quartz show evidence of partial absorption and subsequent dendritic growth. The model for the formation of the matrix rock at the Pitinga Mine considers that the partially crystallized, earlier facies were intruded by the more evolved topaz granite crystal mush, which underwent decompression during emplacement, causing compositional desequilibrium and later re-equilibration at low pressure associated with late fluid stage separation.
\end{abstract}

Keywords: topaz granite, matrix rock texture, Pitinga

INTRODUCTION Hydrothermal tin systems are commonly related to the emplacement at shallow levels of fractionated, hydrous magmas (Lehmann 1990). In this environment, crystallization of medium- to coarse-grained granite, which is forcefully invaded by later, fine-grained material, is common. This material is commonly described texturally as granite porphyry or porphyritic granite, but the significance of the texture is commonly overlooked. Cobbing et al. (1986) and Pitfield et al. (1990) described a sequence of texturally and geochemically evolved granites from the Main Range Province (Malaysia) in which the texturally heterogeneous granites were defined as "two-phase variants". They considered that the two-phase texture is formed when a residual magma undergoes a sudden pressure release, resulting in fluidization and invasion of earlier crystallized coarsergrained granite. The production of the two-phase texture is believed to be an integral part of the process that culminates with the development of tin-bearing massive greisen systems. The aim of this contribution is to describe the petrographic characteristics of the texture, herein termed "matrix rock", and its relationship to the evolution of the Pitinga granites and their associated mineralization. The texture is referred to as "matrix rock" because the proposed origin is slightly different of the hypothesis considered by Pitfield et al. (1990).

GEOLOGICAL SETTING In the Pitinga area, matrix rock is associated with the topaz granite of the Água Boa batholith. The ovalshaped elongated NE-SW Água Boa and Madeira granites (U/Pb age from $1815 \pm 5$ to $1794 \pm 19 \mathrm{Ma}$, Lenharo 1998) intrude acid volcanic and pyroclastic rocks of the Paleoproterozoic Iricoumé Group and are related to a complex fault system. The two bodies contain three major facies, which, in order of emplacement are a fine- to coarse-grained inequigranular to porphyritic rapakivi granite, fine- to medium-grained locally porphyritic biotite granite, and late fine- to coarse-grained porphyritic topaz granite (Água Boa batholith) or fine- to coarsegrained porphyritic albite granite (Madeira pluton) (Fig. 1). Lenharo et al. (1999) suggest that the formation of the batholith occurred by shallow level emplacement of magma via brittle fracture exploitation, with several stages of crystallization due to decompression. Zircon, thorite, monazite, columbite-tantalite, bastnaesite, cassiterite and xenotime are present as accessory minerals in all facies of the Pitinga granites. Tin mineralization in the Água Boa Granite occurs as cassiterite-topaz-mica-quartz greisens and cassiterite-bearing sodic episyenites. In the Madeira Granite, the albite granite contains disseminated cryolite-zircon-cassiterite-pyrochlore-columbite-tantalitexenotime mineralization.

\section{MACROSCOPIC CHARACTERISTICS OF MATRIX ROCK}

The contact between biotite granite and porphyritic topaz granite in drill core from the north-west part of the Água Boa batholith is commonly formed by a 1 to $40 \mathrm{~cm}$ thick zone of matrix rock composed of the coarse- to medium-grained biotite granite surrounded by anastomosing and intergranular masses of fine-grained porphyritic topaz granite. The grains or aggregates of the coarse- to medium-

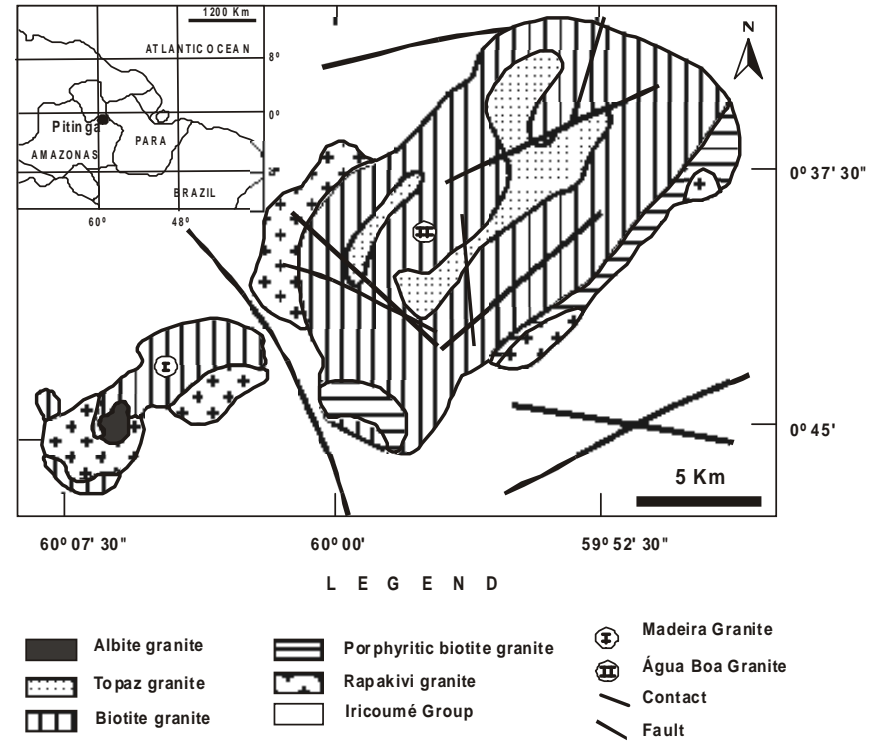

Figure 1 - Geological map of Piting a Mine region (modified from Horbe et al., 1985; Daoud \& Antonietto Jr, 1985; Costi \& Popini, 1994).

grained biotite granite display irregular boundaries and commonly merge with the fine-grained porphyritic topaz granite. The fine-grained porphyritic topaz granite commonly contains phenocrysts displaying a preferred orientation, which may represent a magmatic foliation.

The contact between the porphyritic topaz granite and the rapakivi facies has been observed in drill core from several drill holes located in the western part of the batholith. This contact is also formed by matrix rock, which is commonly 20 to $80 \mathrm{~cm}$ thick in drill core. The matrix rock is composed of masses and intergranular films of finegrained porphyritic topaz granite, which anastomose around the rapakivi portions. The topaz granite component is clearly intrusive and exhibits a flow foliation (Fig. 2).

Where apparently sharper contacts between the porphyritic topaz granite and earlier phases are observed in hand specimen, thin section examination reveals a matrix rock with the intergranular fine-grained porphyritic topaz phase surrounding the earlier, coarser-grained crystals. At this scale, the contact between rapakivi or biotite granite and porphyritic topaz granite is rarely abrupt.

A microgranite phase that is spatially associated with greisens occurs as dykes and/or sills, which crosscut the biotite granite and porphyritic topaz granite. The microgranite varies from $4 \mathrm{~cm}$ to $3 \mathrm{~m}$ in thickness.

TEXTURAL CHARACTERISTICS OF TOPAZ GRANITE The topaz phase of the Água Boa Granite is white-gray to pinkish,

1 - Instituto de Geociências, Universidade de Brasília, Campus Asa Norte, 70910-900, Brasília, Brazil

2 - School of Earth Sciences, James Cook University, Q4811, Townsville, Australia

3 - Departamento de Engenharia de Minas, Escola Politécnica, Universidade de São Paulo, 05508-900, São Paulo, Brazil 


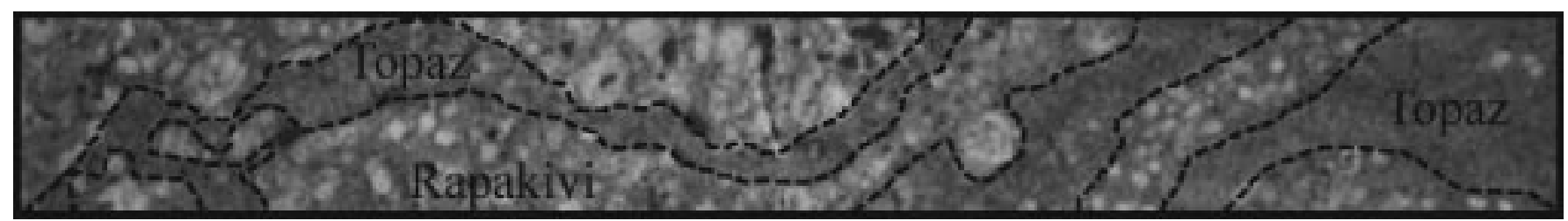

Figure 2 - Flow foliation observed in the contact between rapakivi and topaz granite forming the matrix rock texture. Drill core portion 30 cm long.

\begin{tabular}{|c|c|c|c|c|c|c|c|c|c|c|c|c|c|c|}
\hline \multirow{2}{*}{$\begin{array}{l}\text { Tex. } \\
\text { Type }\end{array}$} & \multirow[t]{2}{*}{ Phenoc. } & \multirow[t]{2}{*}{ Matrix } & \multicolumn{3}{|c|}{ K-fd perthitic } & \multicolumn{3}{|c|}{ Quartz } & \multicolumn{3}{|c|}{ Plagioclase } & \multicolumn{3}{|c|}{ Mica } \\
\hline & & & Phen & Matr & Bulk & Phen & Matr & Bulk & Phen & Matr & Bulk & Phen & Matr & Bulk \\
\hline $\begin{array}{l}\text { End } \\
\text { Member }\end{array}$ & $\begin{array}{l}20 \% \\
(7-35)\end{array}$ & $\begin{array}{l}80 \% \\
(65-93)\end{array}$ & $\begin{array}{l}10 \% \\
(2-20)\end{array}$ & $\begin{array}{l}24 \% \\
(10-30)\end{array}$ & $\begin{array}{l}34 \% \\
(30-37)\end{array}$ & $\begin{array}{l}8 \% \\
(4-10)\end{array}$ & $\begin{array}{l}35 \% \\
(30-40)\end{array}$ & $\begin{array}{l}43 \% \\
(39-48)\end{array}$ & $\begin{array}{l}3 \% \\
(0-7)\end{array}$ & $\begin{array}{l}17 \% \\
(12-20)\end{array}$ & $\begin{array}{l}20 \% \\
(12-25)\end{array}$ & $\begin{array}{l}0 \% \\
(0)\end{array}$ & $\begin{array}{l}3 \% \\
(3-4)\end{array}$ & $\begin{array}{l}3 \% \\
(3-4)\end{array}$ \\
\hline Intermed. & $\begin{array}{l}36 \% \\
(20-50)\end{array}$ & $\begin{array}{l}64 \% \\
(50-80)\end{array}$ & $\begin{array}{l}16 \% \\
(7-25)\end{array}$ & $\begin{array}{l}19 \% \\
(10-30)\end{array}$ & $\begin{array}{l}35 \% \\
(20-45)\end{array}$ & $\begin{array}{l}15 \% \\
(8-35)\end{array}$ & $\begin{array}{l}27 \% \\
(15-38)\end{array}$ & $\begin{array}{l}42 \% \\
(30-55)\end{array}$ & $\begin{array}{l}4 \% \\
(0-15)\end{array}$ & $\begin{array}{l}15 \% \\
(7-18)\end{array}$ & $\begin{array}{l}19 \% \\
(12-28)\end{array}$ & $\begin{array}{l}0.4 \% \\
(0-3)\end{array}$ & $\begin{array}{l}3.6 \% \\
(2-5)\end{array}$ & $\begin{array}{l}4 \% \\
(3-5)\end{array}$ \\
\hline $\begin{array}{l}\text { Matrix } \\
\text { Rock }\end{array}$ & $\begin{array}{l}68 \% \\
(55-90)\end{array}$ & $\begin{array}{l}32 \% \\
(10-45)\end{array}$ & $\begin{array}{l}35 \% \\
(20-45)\end{array}$ & $\begin{array}{l}9 \% \\
(2-15)\end{array}$ & $\begin{array}{l}44 \% \\
(35-50)\end{array}$ & $\begin{array}{l}24 \% \\
(17-38)\end{array}$ & $\begin{array}{l}13 \% \\
(5-20)\end{array}$ & $\begin{array}{l}37 \% \\
(32-43)\end{array}$ & $\begin{array}{l}7 \% \\
(0-15)\end{array}$ & $\begin{array}{l}8 \% \\
(3-10)\end{array}$ & $\begin{array}{l}15 \% \\
(10-23)\end{array}$ & $\begin{array}{l}2 \% \\
(0-3)\end{array}$ & $\begin{array}{l}2 \% \\
(0-3)\end{array}$ & $\begin{array}{l}4 \% \\
(3-5)\end{array}$ \\
\hline
\end{tabular}

inequigranular porphyritic with commonly rounded quartz and rectangular white and pink feldspar phenocrysts $(0.5$ to $3 \mathrm{~cm})$. The groundmass is homogeneous, fine-grained, and composed of quartz, white and pink feldspar, micas (biotite and Li-siderophyllite) and primary magmatic and secondary hydrothermal topaz. Granophyric textures are locally present. The topaz granite contains patches of coarse-grained quartz, mica and fluorite and is cut by mica-quartz veins (greisens).

The porphyritic topaz granite is divided into three textural subtypes according to the abundance and nature of the boundaries of the phenocrysts (Table 1). The subtypes comprise: 1) end-member, containing less than 50\% phenocrysts, regular boundaries; 2) intermediate type, containing less than $50 \%$ phenocrysts, dendritic boundaries probably related to absorption and growth during groundmass crystallization; and 3) matrix rock, containing more than $50 \%$ phenocrysts, absorption and growth features ubiquitous.

Based on the modal composition estimated from thin sections (Table 1) the three textural subtypes of the porphyritic topaz granite display a decrease in perthitic K-feldspar and an increase in quartz and plagioclase from the matrix rock to the end-member. The amount of mica varies only slightly.

The end-member of the porphyritic topaz granite contains coarsegrained phenocrysts (20\%) of subhedral to anhedral K-feldspar and quartz, subhedral plagioclase and rare aggregates of K-feldspar formed on early plagioclase nuclei. The quartz displays slightly dendritic boundaries and rare, small quartz clusters with optical and boundary continuities are observed. Phenocrysts and aggregates of K-feldspar have fine-grained plagioclase and quartz inclusions and less commonly display granophyric intergrowths with quartz. The plagioclase phenocrysts are commonly more Ca-rich in the core as indicated by sericitic alteration.

The groundmass is commonly fine- to medium-grained and composed of anhedral K-feldspar that is weakly perthitic, anhedral to subhedral and vermicular quartz, subhedral albite and anhedral medium-grained green and pale mica (biotite). Quartz and plagioclase slightly interdigite, whereas K-feldspar is late and encloses the former. Biotite occurs either interstitial to the major minerals or filling cavities. Small portions of the groundmass with the same mineralogical composition are fine- to very fine-grained and are commonly associated with or surround the granophyric intergrowth suggesting more rapid crystallization and higher degree of undercooling.

In the intermediate-type quartz, and less commonly K-feldspar and plagioclase phenocrysts (36\%) have dendritic boundaries (Fig. 3). Small quartz clusters with optical and boundary continuities are separated by the fine- to medium-grained groundmass, also suggesting fracturing and absorption with subsequent growth as indicated by inclusions of the groundmass in the border of the phenocrysts. The formation of dendritic intergrowths suggests a high degree of undercooling during groundmass crystallization.

Granophyric textures have been observed to surround phenocrysts and rounded aggregates of K-feldspar. The rounded K-feldspar aggregates formed on early plagioclase nuclei and display swapped albite rims between adjacent grains. Phenocrysts and rounded aggregates of plagioclase are commonly Ca-rich in the core as indicated by sericitic alteration. The K-feldspar and plagioclase

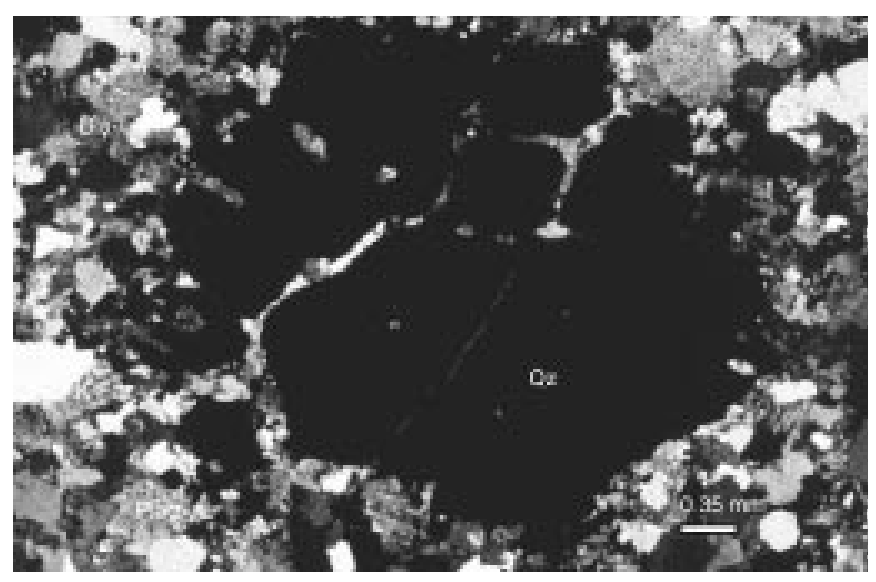

Figure 3 - Fractured quartz phenocryst with optical continuity suggesting absorption and subsequent growth contemporaneous with groundmass formation.

aggregates may represent parts of the intruded host granite (biotite and rapakivi facies). Perthitic K-feldspar rims (anti-rapakivi texture) rarely surround plagioclase. Two types of groundmass are commonly observed: 1) a fine- to medium-grained hypidiomorphic to allotriomorphic granular groundmass; and 2) a fine- to very finegrained completely allotriomorphic groundmass resembling a "quenched" process of crystallization. In the fine- to medium-grained groundmass quartz, K-feldspar and albite are subhedral to anhedral, have slightly interdigitating boundaries and are enclosed by late anhedral K-feldspar. Biotite is commonly interstitial. The fine- to very fine-grained groundmass commonly occurs close to the phenocrysts and merges with the medium groundmass. The mineralogical composition is similar, although the very fine groundmass appears to be richer in quartz.

The matrix rock contains anhedral quartz, subhedral to anhedral Kfeldspar, subhedral plagioclase and mainly K-feldspar and plagioclase aggregates as phenocrysts $(68 \%)$. Rounded aggregates formed by a core of sericitized plagioclase surrounded by a rim of perthitic Kfeldspar and a subsequent external granophyric fringe are common. Granophyric intergrowths only occur on the margins of the rounded aggregates. Only quartz is present as individual phenocrysts with essentially dendritic boundaries.

The aggregates are interpreted to be relicts of the host rock intruded and surrounded by the fine- to medium groundmass. Two types of groundmass are observed in matrix rock samples, a fine- to mediumgrained groundmass and a fine-grained groundmass. The features of these groundmasses are similar to those described in the intermediate type and the fine-grained groundmass either encloses or is interstitial to the medium-grained one, indicating that the former crystallized later than the medium-grained groudmass.

The three types of porphyritic topaz granite have many similar textural characteristics, including dendritic and granophyric intergrowths, zoned plagioclase and commonly two different types of 
groundmass. Also, biotite generally represents less than $5 \%$ of the rock volume, while topaz generally comprises less than $1 \%$ of the rock. Accessory minerals include fluorite, zircon, monazite, opaque Fe-Tioxides, thorite, columbite-tantalite, cassiterite, xenotime, sulphides and a variety of REE-bearing phases. Opaque minerals occur along the mica cleavage.

Topaz occurs as: 1) subhedral to euhedral crystals up to $1 \mathrm{~mm}$ in diameter, and 2) as irregular crystals and crystal aggregates. Topaz is generally associated with albite, and is commonly partially replaced by muscovite. The irregular crystals and aggregates of topaz commonly occur interstitial to other minerals and appear to have formed partly by replacement of feldspar (albite, $\mathrm{K}$-feldspar). This suggests that topaz is both a primary magmatic phase and a secondary, hydrothermal phase.

Alteration minerals include white and pale mica (Li-siderophylite), fluorite, topaz, feldspar and opaque minerals. Topaz, fluorite and sericite fill the interstitial miarolitic cavities.

\section{DISCUSSION OF THE TEXTURAL FEATURES}

The

accessory mineral assemblage and the typical association of columbite with cassiterite is an important indicator of the specialized nature of the melt that formed the topaz granite. According to Lenharo (1998), the topaz granite is predominantly peraluminous, subsolvus and has primary sodic plagioclase and topaz. The estimated temperature of crystallization of the melt using $\mathrm{Zr}$ concentration as a function of melt composition ranges from 800 to $750^{\circ} \mathrm{C}$. The low temperature compared with the earlier facies, $\mathrm{Al}$ enrichment, presence of topaz and position in the Q-Ab-Or diagram toward the haplogranite minimum melt composition at pressures of 1 kbar suggest that its crystallization was related to fractionation in a system enriched in volatiles.

The presence of the topaz matrix rock, which encloses and intrudes the biotite and rapakivi facies, establishes the chronological sequence of emplacement between these facies.

To permit a magma to ascend through the crust, the viscosity must remain low. The increase in crystallinity associated with cooling can preclude ascent by increasing the viscosity. However, in ascending magmas generated from crustal material, the viscosity does not change significantly in any P-T path followed (path with cooling and crystallization or adiabatic path with decompression melting) as long as the crystal fraction is low enough to assume a Newtonian behavior (30-50\% crystals, depending on size and shape) (Holtz et al. 1996). Therefore, the boundary between topaz granite (end-member and intermediate-type) and matrix rock was established on $50 \%$ of phenocrysts that could already have crystallized before ascent of the topaz granite crystal mush.

According to Nekvasil (1991) the major differences between highand low-pressure in the position of the $\mathrm{H}_{2} \mathrm{O}$-undersaturated four-phase surface (plagioclase, quartz, alkali feldspar and melt) in the granite system is the shift to higher quartz contents with decreasing pressure. If the groundmass phases represent melt after re-equilibration at lower pressure, then the groundmass should have higher quartz content than that of the melt that was in equilibrium with the early-formed phenocryst phases. Additionally, Nekvasil (1991) commented that the increase in silica content of the melt that would be required to establish a new equilibrium could be achieved by partial absorption of quartz phenocrysts.

The subdivision of the porphyritic topaz granite (Table 1) indicates that the end-member and intermediate-types have more quartz in the groundmass, suggesting at least two stages of crystallization, at high and low pressure. Furthermore, a contrary trend is observed in the matrix rock, where the content of quartz is higher in the phenocryst portion. This is expected, since the phenocrysts are interpreted as relicts of the biotite and rapakivi facies. The amount of quartz phenocrysts as compared to its occurrence in the groundmass suggests that the topaz granite (end-member and intermediate-type) formed by pressure release. This pressure release probably occurred during emplacement.

In the porphyritic topaz granite and related matrix rock, quartz phenocrysts are medium- to coarse-grained, generally anhedral to subhedral with irregular dendritic boundaries. Additionally, the matrix rock of the porphyritic topaz granite has preserved aggregates of Kfeldspar and plagioclase, but quartz is present only as individual phenocrysts displaying fractures with infilling groundmass, and with dendritic boundaries. This is consistent with the interpretation of absorption and subsequent growth of quartz. It is worth noting that aggregates of plagioclase and K-feldspar, which are interpreted to be relicts of the host rocks, are only present in samples with more than $50 \%$ phenocrysts.

Based on the phase-equilibrium relations in the system albiteorthoclase-quartz- $\mathrm{H}_{2} \mathrm{O}$ determined by Tuttle and Bowen (1958) the dissolution of quartz can be associated with a re-equilibration of the system due to a release of pressure (due to either emplacement or separation of a fluid phase). The phenocrysts in the topaz facies of the Água Boa Granite crystallized at higher pressure and lower degrees of undercooling compared to the groundmass. Release of pressure would have caused compositional disequilibrium in the melt and, in order to achieve equilibrium at the lower pressure conditions, the system would have consumed mainly quartz until it reached the minimum composition again. As soon as the minimum was reached, quartz growth would continue but at lower pressure and higher degree of undercooling, as indicated by the dendritic texture.

The release of pressure could have been due to either physical condition during emplacement, or to separation of a fluid phase. The porphyritic topaz granite is a late phase, which probably had a high content of water and volatiles, and separation of a fluid phase could have caused the release of pressure and increase in the degree of undercooling.

Nekvasil (1991), in relation to rapakivi textures, suggested that $\mathrm{H}_{2} \mathrm{O}$-saturation prior to or during ascent or upon emplacement of the magma would result in rapid crystallization of the groundmass (pressure quench phenomenon) and would not be accompanied by partial absorption of either quartz or alkali feldspar because of the lower $\mathrm{H}_{2} \mathrm{O}$ solubility and hence higher solidus temperature at lower pressures. Considering this fact, emplacement concomitant with decompression is the major cause of quartz absorption by reequilibration of the system at lower pressure. Therefore, in the porphyritic topaz granite, the melt became oversaturated after emplacement and both emplacement and later fluid phase separation may have influenced the subsequent dendritic growth and development of two types of groundmass.

The topaz granite matrix rock at Pitinga has many petrographic features in common with rocks described by Pitfield et al. (1990). However, the hypothesis considered by these authors for the textural evolution is that the primary phases were consolidated prior to disruption, which is at variance with the petrographic features observed at Pitinga, such as gradational transition and absence of absorption of primary phases. Additionally, Pitfield et al. (1990) considered that the formation of microbrecciation, as well as replacement and grain size reduction in the groundmass, occurred at an advanced stage of crystallization associated with fluidization. However, advanced crystallization would form a large volume of phenocrysts and therefore restrict the formation and ascent of evolved phases such as the topaz granite. Fluidization would also result in formation of quench textures, which are not observed at Pitinga.

The crystallization of the Pitinga matrix rock prior to emplacement, as indicated by the abundance of phenocrysts, appears to have been small, since the amount of phenocrysts in the end-member is low, and in the other types, phenocrysts are considered to be relicts of the primary phases. The groundmass is typically medium-grained and only locally resembles quenched material, which would be expected during fluidization.

The development of the matrix rock at Pitinga is attributed to pressure release during the emplacement of the residual topaz granitic crystal mush (30-50\% crystals) which intruded the partially crystallized biotite and/or rapakivi granite facies. Under the lower pressure conditions during crystallization and re-equilibration of the matrix rock, plagioclase and K-feldspar aggregates of the earlier facies were preserved while quartz was consumed. At low pressure, the undersaturated minimum in the haplogranite system is shifted to the albite-rich compositions, and quartz growth has recommenced. Later fluid phase separation caused the formation of groundmasses of two grain-sizes, and was associated with formation of microgranites and greisen-style tin mineralization. 


\section{References}

Cobbing E.J., Mallick, D.I.J., Pitfield, P.E.J., Teoh, L.H. 1986. The granites of the Southeast Asian Tin Belt. Journal of the Geological Society of London, 143:537-550

Costi H.T. and Popini M.V.F. 1994. Relatório Interno, Mina de Pitinga, Grupo Paranapanema. Inédito.

Daoud W.E.K. and Antonietto Junior A. 1985. Geologia do granito estanífero Água Boa Pitinga, AM. II Simpósio de Geologia da Amazônia, Anais ..., Belém, SBG/NN 3:17-33.

Holtz F., Scaillet B., Behrens H., Schulze F., Pichavant M. 1996. Water contents of felsic melts: application to the rheological properties of granitic magmas. Transactions of the Royal Society of Edinburgh: Earth Sciences, 87:57-64.

Horbe M.A., Horbe A.C., Teixeira J.T., Costi H.T. 1985. Granito Madeira: petrologia, petroquímica e mineralizações. II Simpósio de Geologia da Amazônia, Anais ... Belém, SBG/NN, 3:284-320.

Lehmann B. 1990. Metallogeny of tin. Lecture Notes in Earth Sciences, 32. Spring-Verlag, $211 \mathrm{p}$.

Lenharo S.L.R. 1998. Evolução magmática e modelo metalogenético dos granitos mineralizados da região de Pitinga, Amazonas, Brasil. Universidade de São Paulo, Tese de Doutorado, São Paulo, 290 p.
Lenharo S.L.R., Pollard P.J., Born H. 1999. Petrologic evolution and emplacement of the mineralised Pitinga Granites, Brazil. In: IVth Hutton Symposium, Clermont-Ferrand, 1999. Document du BRGM, 290:236

Nekvasil H. 1991. Ascent of felsic magmas and formation of rapakivi. American Mineralogist, 76:1279-1290.

Pitfield P.E.J., Teoh L.H., Cobbing E.J. 1990. Textural variation and tin mineralization in granites from the Main Range Province of the Southeast Asian Tin Belt. Geological Journal, 25:419-429.

Tuttle O.F. and Bowen N.L. 1958. Origin of granite in the light of experimental studies in the system $\mathrm{NaAlSi}_{3} \mathrm{O}_{8}-\mathrm{KAlSi}_{3} \mathrm{O}_{8}-\mathrm{SiO}_{2}-\mathrm{H}_{2} \mathrm{O}$. The Geological Society of America, 74:153 p.

Contribution IGC-109

Received March 2, 2000 Accepted for publication April 27, 2000 